\title{
POSITIVITY OF SUMS AND INTEGRALS FOR CONVEX FUNCTIONS OF HIGHER ORDER OF $n$ VARIABLES
}

\author{
ASIF R. KHAN, Josip PEČARIĆ AND SANJA VAROŠANEC
}

\begin{abstract}
We provide one general discrete identity for $\sum \cdots \sum P_{k_{1} \cdots k_{n}} f\left(x_{1 k_{1}}, \ldots, x_{n k_{n}}\right)$ and one general integral identity for $\Lambda(f)=\int \cdots \int P\left(x_{1}, \ldots, x_{n}\right) f\left(x_{1}, \ldots, x_{n}\right) d x_{1} \cdots d x_{n}$ of Popoviciu type. We obtain necessary and sufficient conditions under which these sum and integral are nonnegative for higher order convex functions of $n$ variables. These identities and inequalities generalize various established results. We also state new generalized Lagrange type and Cauchy type mean value theorems. We obtain an Ostrowski type result as a special case of our main integral identity and we also establish a bound on remainder term of our main integral identity in terms of $L_{p}$-norm by using Hölder's inequality. Finally we apply the functional $\Lambda(f)$ on the family of some exponentially convex functions and discuss some of its major properties.
\end{abstract}

Mathematics subject classification (2010): 26A51, 39B62, 26D15, 26D20, $26 \mathrm{D} 99$.

Keywords and phrases: Convex function of higher order, exponential-convexity.

\section{REFERENCES}

[1] S. N. Bernstien, Sur les fonctions absolument monotones, Acta Math. 52 (1929), 1-66.

[2] S. S. DRAGOMIR AND T. M. RASSiAS, Ostrowski type inequalities and applications in numerical integration, Kluwer Academics Publishers, Dordrecht, 2002.

[3] J. JAKŠEtiĆ AND J. E. PeČARIĆ, Exponential convexity method, J. Convex Anal., 20 (1) (2013), 181-197.

[4] A. R. Khan, N. LATIF And J. E. PeČARIĆ, Exponential convexity for majorization, J. Inequal. Appl., 2012 (2012): 105, 1-13.

[5] A. R. Khan, J. E. PeČarić And S. Varošanec, Popoviciu type characterization of positivity of sums and integrals for convex functions of higher order, J. Math. Inequal., 7 (2) (2013), 195-212.

[6] J. E. PeČARIĆ, An inequality for m-convex sequences, Matematički Vesnik, 5 (18)(33) (1981), 201203.

[7] J. E. PEČARIĆ, Some further remarks on the Ostrowski generalization of Čebyšev's inequality, J. Math. Anal. Appl., 123 (1) (1987), 18-33.

[8] J. E. PeČarić, F. Proschan And Y. L. Tong, Convex functions, Partial Orderings and Statistical Applications, Academic Press, New York, 1992.

[9] J. E. PeČArić, B. A. Mesihović, I. Ž. Milovanović and N. Stojanović, On some inequalities for convex and $\nabla$-convex sequences of higher order I, Period. Math. Hungar., 17 (3) (1986), 235-239.

[10] J. E. PeČArić, B. A. Mesihović, I. Ž. Milovanović And N. Stojanović, On some inequalities for convex and $\nabla$-convex sequences of higher order II, Period. Math. Hungar., 17 (4) (1986), 313-320.

[11] T. Popoviciu, Introduction à la théorie des différences divisées, Bull. Math. Soc. Roumaine Sci., 42 (1) (1941), 65-78.

[12] P. K. SAHoo And T. Riedel, Mean value theorems and functional equations, World Scientific Publishing Co., Inc., River Edge, NJ, 1998. 